\title{
ANALISIS PERTUMBUHAN EKONOMI DAN DISPARITAS PENDAPATAN DI KABUPATEN JEMBER TAHUN 2008-2011
}

Oleh:

\section{Davi Eko Prasetyo}

\author{
Davi Eko Prasetyo \\ davi_ekopras@yahoo.co.id \\ Jurusan Ilmu Ekonomi Studi Pembangunan \\ Fakultas Ekonomi \\ Universitas Muhammadiyah Malang
}

\begin{abstract}
The aim of this research is to know the economic development among Districts in the Jember Regency, know each classification among Districts in the Jember Regency based Klassen Typology and know the income disparity among Districts in the Jember Regency. Analysis result using regional economic development method, shows that total of PDRB development average in the Jember Regency is $5.38 \%$ from 2008 to the 2011. Analysis result of Klassen Typology determining for $1^{\text {st }}$ Classification: 1) The region develops and grows fast, in the Jember Regency, this classification contain of 8 Districts. 2) $2^{\text {nd }}$ Classification: The region developed, but also depressed, in the Jember Regency, this classification contain of 3 Districts, 3) $3^{\text {rd }}$ Classification: Fast developed region, in the Jember Regency, this classification contain of 12 Districts, 4) $4^{\text {th }}$ Classification: Poor region, in the Jember Regency, this classification contain of 8 Districts. The result of Williamson index average number that reach the highest value is in the Mumbul Sari and Pakusari Districts. Whereas, for income disparity number or the lowest discrepancy index is in the Rambi Puji District. Thus, income disparity or discrepancy among Districts in the Jember Regency shows the index average of income disparity or economic discrepancy that really high in 2008 to the 2011.
\end{abstract}

Keyword: Growth Of Economics, Pattern Growth and of Disparitas Earnings.

\section{PENDAHULUAN}

Pembangunan ekonomi dapat diartikan sebagai suatu proses yang menyebabkan pendapatan perkapita penduduk suatu masyarakat meningkat. Dimana kenaikan pendapatan perkapita merupakan suatu pencerminan dari timbulnya perbaikan dalam kesejahteraan ekonomi masyarakat. Tujuan utama dari usaha-usaha pembangunan ekonomi selain menciptakan pertumbuhan ekonomi yang tinggi, seharusnya dapat pula menghapus atau mengurangi tingkat kemiskinan, 
kesenjangan pendapatan dan tingkat pengangguran (Todaro, 2004).

Kesenjangan

atau

ketimpangan pendapatan akan

menimbulkan berbagai

permasalahan. Permasalahan tersebut dapat berupa peningkatan migrasi dari Daerah yang miskin ke Daerah yang lebih maju, kriminalitas, konflik antar masyarakat, dan dalam konteks kenegaraan, kesenjangan akan mengurangi kepercayaan masyarakat terhadap pemerintah yang kemudian akan mengancam keutuhan suatu Negara. Hal ini tentu akan mengganggu proses produksi dan aktivitas ekonomi suatu Negara.

Secara administratif wilayah Kabupaten Jember terbagi menjadi 31 kecamatan terdiri atas 28 kecamatan dengan 225 desa dan 3 kecamatan dengan 22 kelurahan (sumber:

http://id.wikipedia.org/wiki/Kabupat enJember). Dimana untuk jumlah penduduk di Kabupaten Jember pada tahun 2008 sampai dengan tahun 2011 dapat dilihat pada Gambar 1.

Gambar 1. Jumlah Penduduk Kabupaten Jember Tahun 2008-2011 (Jiwa)

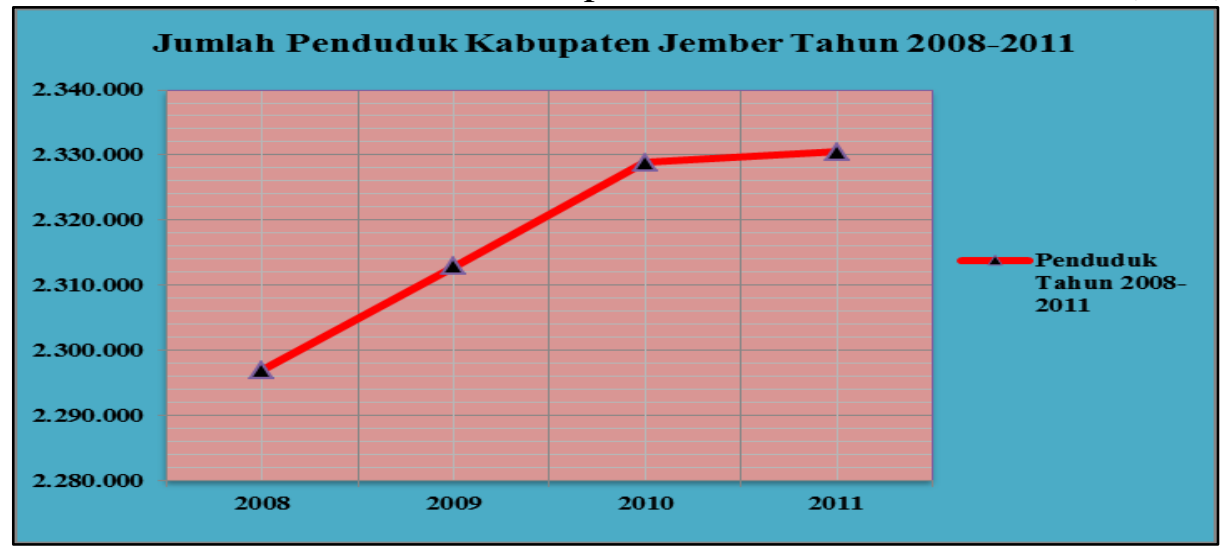

Sumber: Diolah dari BPS Provinsi Jatim, 2013.

Selanjutnya pertumbuhan PDRB atas dasar harga konstan di Kabupaten Jember pada tahun 2008 sampai dengan tahun 2011 dapat dilihat pada Gambar 2.

Beberapa penelitian terdahulu mengenai pertumbuhan ekonomi dan ketimpangan telah banyak dilakukan, antara lain: Penelitian seperti yang telah dilakukan oleh Sutarno \& Mudrajad Kuncoro (2003) melakukan penelitian tentang pertumbuhan ekonomi dan ketimpangan antar kecamatan di Kabupaten Banyumas pada tahun 1993-2000. Dengan menggunakan 
alat analisis Tipologi Klassen, Indeks Williamson, Indeks Theil, dan Trend Korelasi Pearson. Hasil penelitian menunjukkan dari 27 kecamatan yang ada di Kabupaten Banyumas terdapat 7 kecamatan yang termasuk daerah cepat maju dan cepat tumbuh, 3 kecamatan termasuk daerah maju dan tertekan, 6 kecamatan termasuk kecamatan berkembang cepat, dan sisanya sebanyak 11 kecamatan termasuk daerah relatif tertinggal.

Gambar 2. Pertumbuhan PDRB ADHK Kabupaten Jember Tahun 20082011

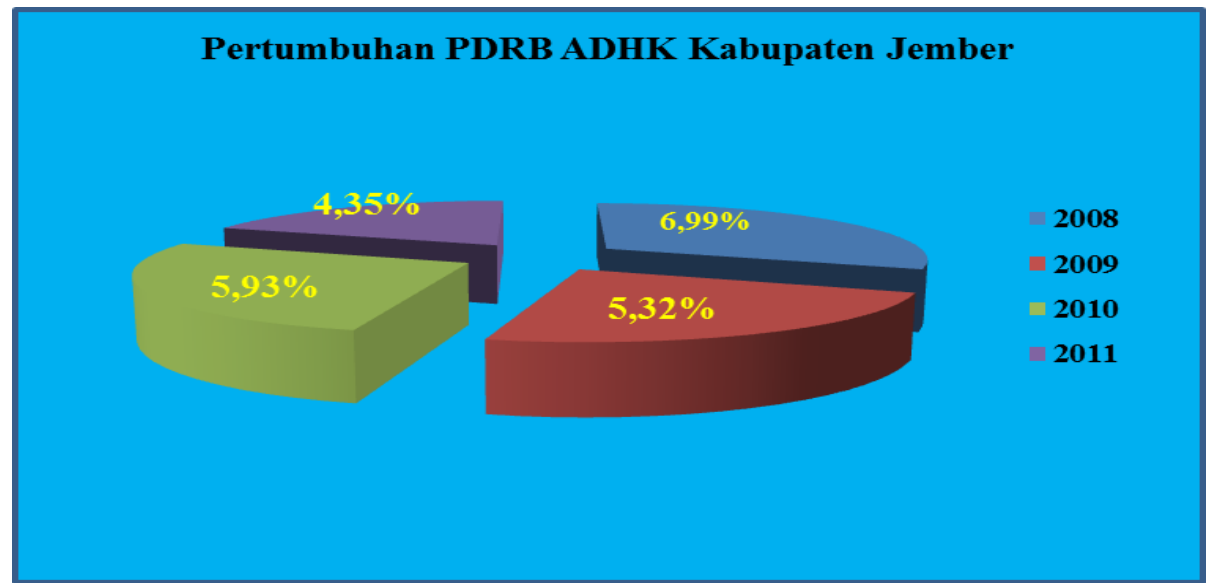

Sumber: Diolah dari BPS Provinsi Jatim, 2013.

Rata-rata Indeks Williamson dan Indeks Entropi Theil selama periode 1993-1997 masing-masing sebesar 0,426 dan 0,039. Hasil keduanya menunjukkan terjadinya kecenderungan peningkatan ketimpangan di Kabupaten Banyumas. Selain itu pembuktian Hipotesis Kuznets berlaku di Kabupaten Banyumas.

Perbedaan penelitian ini dibandingkan penelitian sebelumnya adalah unit analisisnya. Peneliti sekarang menggunakan objek atau Daerah antar Kecamatan di
Kabupaten Jember Provinsi Jawa Timur mulai pada tahun 2008 sampai dengan tahun 2011. Alat analisis yang digunakan adalah pola pertumbuhan sektor ekonomi menggunakan Tipologi Klassen, analisis kontribusi, analisis tingkat ketimpangan pendapatan ekonomi antar Kecamatan di Kabupaten Jember dengan menggunakan Indeks Williamson. Sedangkan persamaan dalam penelitian adalah sama-sama mengidentifikasi perekonomian regional. 
METODE PENELITIAN

Penelitian ini dilakukan dilokasi 31 Kecamatan di Kabupaten Jember Provinsi Jawa Timur. Jenis penelitian yang dilakukan adalah bersifat penelitian deskriptif kuantitatif. Data pada penelitian ini diambil dari Badan Pusat Statistik (BPS) di Badan Pusat Statistik (BPS) Propinsi Jawa Timur (Jawa Timur Dalam Angka 2012) yang telah diterbitkan, yaitu: Data mengenai Produk Domestik Regional Bruto (PDRB) atas dasar harga konstan 2000 per-sektor setiap Kecamatan sejak tahun 2008 sampai dengan tahun 2011, Data Produk Domestik Regional Bruto (PDRB) di Kabupaten Jember atas dasar harga konstan 2000 per-sektor sejak tahun 2008 sampai dengan tahun 2011, Data Jumlah Penduduk Masingmasing Kecamatan di Kabupaten Jember Provinsi Jawa Timur sejak tahun 2008 sampai dengan tahun 2011 dan data-data lain yang dibutuhkan dalam penelitian.

Adapun obyek variabel dan definisi operasional penelitian yang digunakan adalah sebagai berikut: Pertama, Pertumbuhan ekonomi dapat dilihat dari perubahan indikator ekonomi makro yaitu perubahan Pendapatan Domestik Regional Bruto (PDRB) menurut harga konstan masing-masing Kecamatan di Kabupaten Jember Provinsi Jawa Timur, dengan satuan persen. Pertumbuhan yang dimaksudkan adalah pertumbuhan ekonomi PDRB ADHK 2000 rata-rata sejak tahun 2008 sampai dengan tahun 2011 pada masing-masing Kecamatan di Kabupaten Jember Provinsi Jawa Timur.

Kedua, Analisa kontribusi adalah analisa yang digunakan untuk mengetahui kontribusi suatu daerah terhadap daerah yang lebih luas misalnya jumlah Produk Domestik Regional Bruto (PDRB) sektor atau sub sektor tertentu terhadap total Produk Domestik Regional Bruto (PDRB). Ketiga, Kesenjangan regional adalah merupakan suatu keadaan yang merupakan tingkat perbedaan tingkat pembangunan dan pendapatan antara Kabupaten atau daerah yang satu dengan yang lain. Kesenjangan regional ini dapat diketahui dengan menggunakan suatu alat analisis yang dinamakan Indeks Williamson, yang dapat 
dihitung dengan data PDRB atas dasar harga konstan.

Keempat, Ketimpangan pendapatan adalah perbedaan pendapatan pada suatu daerah dengan daerah lain yang berada dalam suatu wilayah. Satuan yang digunakan untuk mengukur tingkat ketimpangan pendapatan adalah Indeks Williamson. Kelima, Pendapatan Perkapita merupakan perkiraan pendapatan perorangan yang dihasilkan dari PDRB pertahun dibagi dengan jumlah penduduk pada pertengahan tahun atau dengan kata lain pendapatan perkapita merupakan hasil bagi pendapatan regional dengan jumlah penduduk pertengahan tahun.

Keenam, Penduduk. BPS mendefinisikan bahwa yang dimaksud dengan penduduk adalah semua orang yang berdomisili atau menetap di wilayah geografis Republik Indonesia selama 6 (enam) bulan atau lebih dan atau mereka yang berdomisili kurang dari 6 (enam) bulan tetapi bertujuan untuk menetap atau bertempat tinggal (dalam satuan jiwa).
Ketujuh, Sektor-Sektor Ekonomi. Terdapat sembilan sektor ekonomi disetiap Daerah Kabupaten/Kota maupun wilayah Provinsi. Adapun sektor-sektor perekonomian dimaksud yakni sebagai berikut: Pertanian, Pertambangan \& Penggalian, Industri Pengolahan, Listrik, Gas dan Air Bersih, Bangunan, Perdagangan, Hotel dan Restoran, Angkutan dan Komunikasi, Keuangan Perusahaan, Persewaan dan Jasa Perusahaan, Jasa-jasa.

\section{PEMBAHASAN}

Hasil analisis pertumbuhan PDRB antar masing-masing Kecamatan di Kabupaten Jember selama kurun waktu tahun 20082011, beserta rata-ratanya. Maka tingkat pertumbuhan PDRB ADHK Kecamatan di Kabupaten Jember dapat dilihat pada Tabel 1.

Selanjutnya untuk nilai ratarata pertumbuhan PDRB pada masing-masing Kecamatan di Kabupaten Jember dari tahun 2008 sampai dengan tahun 2011 dapat dilihat pada sajian Gambar 2. 
Tabel 1. Pertumbuhan PDRB ADHK 2000 Kecamatan Di Kabupaten Jember Tahun 2008-2011

\begin{tabular}{|c|c|c|c|c|c|c|}
\hline \multicolumn{2}{|c|}{ Pertumbuhan PDRB } & \multicolumn{2}{|c|}{$\begin{array}{r}\text { ADHK Kecamatan Di } \\
\text { Tahun } 2008-2011\end{array}$} & \multicolumn{3}{|c|}{ Kabupate n Je mbe r 2000} \\
\hline No & Kecamatan & 2008 & 2009 & 2010 & 2011 & Rata-rata \\
\hline 1 & Kencong & 4,64 & 5,36 & 5,46 & 5,57 & 5,26 \\
\hline 2 & Gumuk mas & 6,35 & 6,37 & 5,40 & 5,58 & 5,92 \\
\hline $\mathbf{3}$ & Puger & 5,13 & 5,17 & 5,33 & 6,68 & 5,58 \\
\hline 4 & \begin{tabular}{|l|} 
Wuluhan \\
\end{tabular} & 5,65 & 5,57 & 5,80 & 6,43 & 5,86 \\
\hline 5 & Ambulu & 4,95 & 5,45 & 5,67 & 6,03 & 5,52 \\
\hline 6 & Tempu rejo & 4,30 & 5,44 & 5,55 & 5,74 & 5,26 \\
\hline 7 & Silo & 5,22 & 5,58 & 5,60 & 5,79 & 5,55 \\
\hline 8 & Mayang & 4,95 & 5,52 & 5,66 & 6,37 & 5,62 \\
\hline 9 & Mumbul s ari & 3,32 & 0,81 & 10,22 & 5,40 & 4,94 \\
\hline 10 & Jengg awah & 6,70 & 6,72 & 5,64 & 6,08 & 6,28 \\
\hline 11 & Ajung & 5,43 & 5,51 & 5,68 & 0,18 & 4,20 \\
\hline 12 & Rambi puji & 2,95 & 2,70 & 6,16 & 7,20 & 4,75 \\
\hline 13 & Balung & 5,26 & 5,62 & 6,21 & 7,10 & 6,05 \\
\hline 14 & Umbul s ari & 2,08 & 1,66 & 5,41 & 5,49 & 3,66 \\
\hline 15 & Semboro & 4,92 & 5,45 & 5,34 & 5,53 & 5,31 \\
\hline 16 & Jombang & 5,03 & 5,42 & 5,70 & 5,82 & 5,49 \\
\hline 17 & Sumber baru & 5,43 & 5,54 & 5,53 & 6,02 & 5,63 \\
\hline 18 & Tanggul & 3,48 & 1,92 & 5,48 & 5,88 & 4,19 \\
\hline 19 & Bangs al s ari & 4,88 & 5,49 & 5,61 & 6,06 & 5,51 \\
\hline 20 & Panti & 4,05 & 5,42 & 5,15 & 5,34 & 4,99 \\
\hline 21 & Suko rambi & 5,80 & 5,47 & 5,46 & 5,92 & 5,66 \\
\hline 22 & Arjas a & 4,38 & 5,55 & 5,67 & 6,23 & 5,46 \\
\hline 23 & Pakus ari & 5,67 & 5,49 & 5,43 & 5,83 & 5,60 \\
\hline 24 & Kalis at & 4,34 & 5,63 & 5,96 & 6,59 & 5,63 \\
\hline 25 & Ledok ombo & 5,83 & 5,47 & 5,21 & 5,26 & 5,45 \\
\hline 26 & Sumber jambe & 5,11 & 5,40 & 3,87 & 5,93 & 5,08 \\
\hline 27 & \begin{tabular}{|l|} 
Suko wono \\
\end{tabular} & 4,93 & 5,63 & 5,93 & 6,86 & 5,84 \\
\hline 28 & Jelbuk & 14,83 & 5,53 & 1,46 & 9,65 & 7,87 \\
\hline 29 & Kaliwates & 7,17 & 5,73 & 7,17 & 9,48 & 7,39 \\
\hline $\mathbf{3 0}$ & Sumber sari & 4,43 & 5,77 & 7,06 & $-15,27$ & 0,50 \\
\hline 31 & Patrang & 4,84 & 5,78 & 7,01 & 9,17 & 6,70 \\
\hline & PDRB Jember & 5,23 & 5,10 & 5,70 & 5,48 & \\
\hline
\end{tabular}

Sumber: diolah dari BPS Provinsi Jatim, 2013

Gambar 2. Rata-rata Pertumbuhan PDRB ADHK Kecamatan Di Kabupaten Jember Tahun 2008-2011

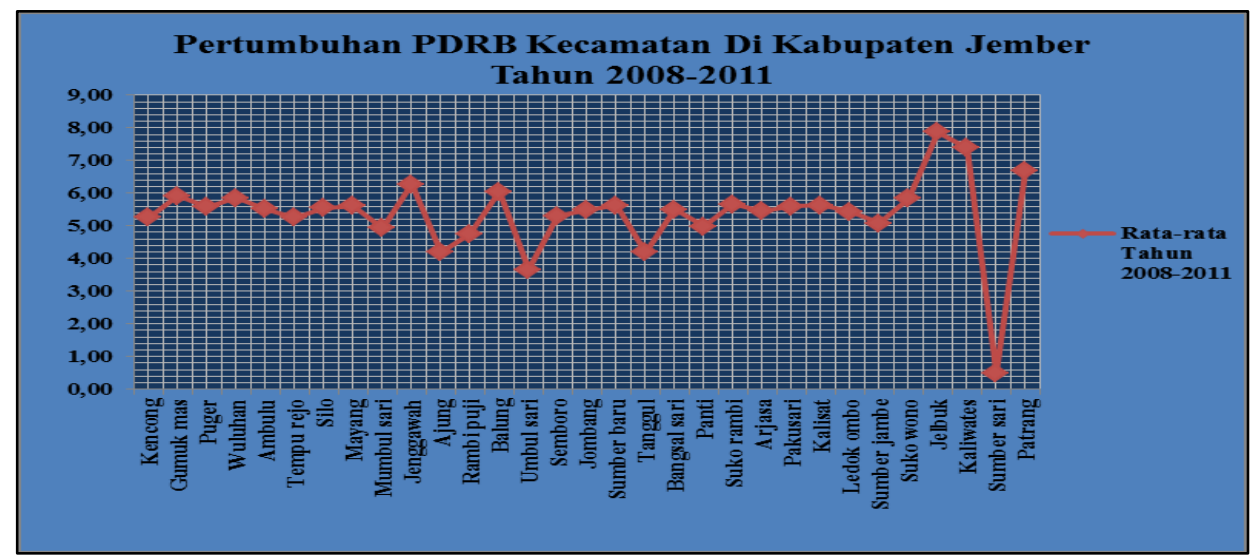

Sumber: diolah dari BPS Provinsi Jatim, 2013

Hasil dari kontribusi sektoral terhadap PDRB atas dasar harga konstan pada masing-masing Kecamatan di Kabupaten Jember mulai tahun 2008 sampai dengan tahun 2011 dapat dilihat pada Tabel 2. 
Tabel 2. Kontribusi Sektor Pertanian Pada Kecamatan Di Kabupaten Jember Tahun 2008-2011

\begin{tabular}{|c|c|c|c|c|c|c|}
\hline \multicolumn{7}{|c|}{ Kontribusi Sektor Pertanian Tahum 2008-2011 } \\
\hline No & Kecamatan & 2008 & 2009 & 2010 & 2011 & Rata-rata \\
\hline 1 & Kencong & 3,67 & 3,67 & 3,67 & 3,67 & 3,67 \\
\hline 2 & Gumuk mas & 4,19 & 4,19 & 4,19 & 4,20 & 4,19 \\
\hline 3 & Puger & 8,76 & 8,70 & 8,71 & 8,71 & 8,72 \\
\hline 4 & Wuluhan & 6,34 & 6,35 & 6,34 & 6,34 & 6,34 \\
\hline 5 & Ambulu & 8,21 & 8,21 & 8,22 & 8,21 & 8,21 \\
\hline 6 & Tempu re.jo & 2,74 & 2,74 & 2,74 & 2,74 & 2,74 \\
\hline 7 & Silo & 5,29 & 5,29 & 5,30 & 5,29 & 5,29 \\
\hline 8 & Mayang & 1,31 & 1,31 & 1,31 & 1,31 & 1,31 \\
\hline 9 & Mumbul sari & 2,02 & 2,02 & 2,02 & 2,02 & 2,02 \\
\hline 10 & Jenggawah & 3,03 & 3,04 & 3,03 & 3,03 & 3,03 \\
\hline 11 & A.jung & 2,41 & 2,41 & 2,41 & 2,41 & 2,41 \\
\hline 12 & Rambi puji & 2,77 & 2,77 & 2,77 & 2,77 & 2,77 \\
\hline 13 & B alung & 2,25 & 2,25 & 2,25 & 2,26 & 2,25 \\
\hline 14 & Umbul s ari & 3,70 & 3,70 & 3,71 & 3,71 & 3,70 \\
\hline 15 & Semboro & 2,01 & 2,01 & 2,01 & 2,01 & 2,01 \\
\hline 16 & Jombang & 1,56 & 1,56 & 1,57 & 1,57 & 1,57 \\
\hline 17 & Sumber baru & 6,14 & 6,15 & 6,15 & 6,14 & 6,14 \\
\hline 18 & Tanggul & 5,21 & 5,21 & 5,20 & 5,20 & 5,21 \\
\hline 19 & Bangsal sari & 6,68 & 6,68 & 6,67 & 6,67 & 6,67 \\
\hline 20 & Panti & 3,24 & 3,24 & 3,23 & 3,23 & 3,24 \\
\hline 21 & Suko rambi & 1,06 & 1,06 & 1,06 & 1,06 & 1,06 \\
\hline 22 & Arjasa & 1,15 & 1,15 & 1,15 & 1,15 & 1,15 \\
\hline 23 & Pakus ari & 1,11 & 1,12 & 1,12 & 1,12 & 1,12 \\
\hline 24 & Kalis at & 2,36 & 2,36 & 2,36 & 2,36 & 2,36 \\
\hline 25 & Ledok ombo & 2,68 & 2,68 & 2,68 & 2,68 & 2,68 \\
\hline 26 & Sumber jambe & 2,60 & 2,61 & 2,61 & 2,61 & 2,61 \\
\hline 27 & Suko wono & 1,92 & 1,93 & 1,93 & 1,93 & 1,93 \\
\hline 28 & Jelbuk & 0,87 & 0,87 & 0,87 & 0,87 & 0,87 \\
\hline 29 & Kaliwates & 1,05 & 1,05 & 1,05 & 1,06 & 1,05 \\
\hline 30 & Sumbersari & 2,06 & 2,06 & 2,06 & 2,06 & 2,06 \\
\hline 31 & Patrang & 1,60 & 1,60 & 1,60 & 1,60 & 1,60 \\
\hline & Total & 100,00 & 100,00 & 100,00 & 100,00 & 100,00 \\
\hline
\end{tabular}

Sumber: diolah dari BPS Provinsi Jatim, 2013

Disamping itu dapat terhadap PDRB atas dasar harga dijelaskan atas hasil analisa konstan di Kabupaten Jember mulai kontribusi untuk sektor tahun 2008 sampai dengan tahun

Pertambangan dan Penggalian dalam peranan kontribusi terhadap PDRB atas dasar harga konstan pada masing-masing Kecamatan di Kabupaten Jember mulai dari tahun 2008 sampai dengan tahun 2011 dapat dilihat dalam sajian Tabel 3.

Selanjutnya dapat dijelaskan atas hasil analisa kontribusi dari peranan sektor Industri Penggolahan pada masing-masing Kecamatan 2011 dapat dilihat dalam sajian Tabel 4.

Sedangkan hasil analisa kontribusi dari peranan Sektor Listrik, Gas \& Air Bersih pada masing-masing Kecamatan terhadap PDRB atas dasar harga konstan di Kabupaten Jember mulai tahun 2008 sampai dengan tahun 2011 dapat dilihat dalam sajian Tabel 5 . 
Tabel 3. Kontribusi Sektor Pertambangan dan Penggalian Pada Kecamatan Di Kabupaten Jember Tahun 2008-2011

\begin{tabular}{|c|c|c|c|c|c|c|}
\hline \multicolumn{7}{|c|}{ Kontribusi Sektor Pertambangan \& Penggalian Tahun 2008-2011 } \\
\hline No & Kecamatan & 2008 & 2009 & 2010 & 2011 & Rata-rata \\
\hline 1 & Kencong & 2,55 & 2,55 & 2,55 & 2,55 & 2,55 \\
\hline 2 & Gumuk mas & 3,55 & 3,55 & 3,55 & 3,55 & 3,55 \\
\hline 3 & Puger & 6,79 & 6,80 & 6,79 & 6,79 & 6,79 \\
\hline 4 & \begin{tabular}{|l|} 
Wuluhan \\
\end{tabular} & 6,95 & 6,96 & 6,95 & 6,95 & 6,95 \\
\hline 5 & Ambulu & 6,19 & 6,20 & 6,19 & 6,19 & 6,19 \\
\hline 6 & Tempu rejo & 2,85 & 2,85 & 2,85 & 2,85 & 2,85 \\
\hline 7 & Silo & 5,12 & 5,12 & 5,12 & 5,12 & 5,12 \\
\hline 8 & Mayang & 1,15 & 1,15 & 1,15 & 1,15 & 1,15 \\
\hline 9 & Mumbul s ari & 1,87 & 1,81 & 1,87 & 1,87 & 1,86 \\
\hline 10 & Jenggawah & 3,22 & 3,22 & 3,22 & 3,22 & 3,22 \\
\hline 11 & Ajung & 2,65 & 2,65 & 2,65 & 2,65 & 2,65 \\
\hline 12 & Rambi pujii & 3,00 & 3,00 & 3,00 & 3,00 & 3,00 \\
\hline 13 & Balung & 3,27 & 3,27 & 3,27 & 3,27 & 3,27 \\
\hline 14 & Umbul s ari & 2,93 & 2,93 & 2,93 & 2,93 & 2,93 \\
\hline 15 & Semboro & 1,15 & 1,15 & 1,15 & 1,15 & 1,15 \\
\hline 16 & \begin{tabular}{|l|} 
Jombang \\
\end{tabular} & 1,51 & 1,51 & 1,51 & 1,51 & 1,51 \\
\hline 17 & Sumbe $r$ baru & 5,63 & 5,63 & 5,63 & 5,63 & 5,63 \\
\hline 18 & Tanggul & 3,64 & 3,64 & 3,64 & 3,64 & 3,64 \\
\hline 19 & Bangs al sari & 6,55 & 6,56 & 6,56 & 6,55 & 6,56 \\
\hline 20 & Panti & 1,80 & $\mathbf{1 , 8 0}$ & 1,80 & $\mathbf{1 , 8 0}$ & $\mathbf{1 , 8 0}$ \\
\hline 21 & Suko rambi & $\mathbf{0 , 7 3}$ & $\mathbf{0 , 7 3}$ & $\mathbf{0 , 7 3}$ & $\mathbf{0 , 7 3}$ & 0,73 \\
\hline 22 & Arjasa & 0,83 & 0,83 & 0,83 & 0,83 & 0,83 \\
\hline 23 & Pakus ari & 0,86 & 0,86 & 0,86 & 0,86 & 0,86 \\
\hline 24 & Kalis at & 2,61 & 2,61 & 2,61 & 2,61 & 2,61 \\
\hline 25 & Ledok ombo & 2,00 & 2,00 & 2,00 & 2,00 & 2,00 \\
\hline 26 & Sumber jambe & 1,79 & 1,79 & 1,79 & 1,79 & 1,79 \\
\hline 27 & Suko wono & 1,82 & 1,82 & 1,82 & 1,82 & $\mathbf{1 , 8 2}$ \\
\hline 28 & Jelbuk & 0,52 & $\mathbf{0 , 5 2}$ & 0,52 & 0,52 & 0,52 \\
\hline 29 & Kaliwates & 5,16 & 5,17 & 5,15 & 5,16 & 5,16 \\
\hline 30 & Sumber sari & 6,86 & 6,86 & 6,86 & 6,86 & 6,86 \\
\hline 31 & Patrang & 4,46 & 4,47 & 4,46 & 4,46 & 4,46 \\
\hline & Total & 100,00 & 100,00 & 100,00 & 100,00 & 100,00 \\
\hline
\end{tabular}

Sumber: diolah dari BPS Provinsi Jatim, 2013

Tabel 4. Kontribusi Sektor Industri Penggolahan Pada Kecamatan Di Kabupaten Jember Tahun 2008-2011

\begin{tabular}{|c|c|c|c|c|c|c|}
\hline \multicolumn{7}{|c|}{ Kontribusi Sektor Industri Penggolahan Tahun 2008-2011 } \\
\hline No & Kecamatan & 2008 & 2009 & 2010 & 2011 & Rata-rata \\
\hline $\mathbf{1}$ & Kencong & $\mathbf{0 , 6 9}$ & $\mathbf{0 , 6 9}$ & $\mathbf{0 , 6 9}$ & $\mathbf{0 , 6 9}$ & $\mathbf{0 , 6 9}$ \\
\hline 2 & Gumuk mas & $\mathbf{1 , 2 7}$ & $\mathbf{1 , 2 6}$ & $\mathbf{1 , 2 7}$ & $\mathbf{1 , 2 7}$ & $\mathbf{1 , 2 7}$ \\
\hline 3 & Puger & $\mathbf{8 , 9 1}$ & 8,90 & 8,68 & 8,91 & 8,85 \\
\hline 4 & Wuluhan & 7,30 & 7,29 & 7,32 & 7,30 & 7,30 \\
\hline 5 & Ambulu & 5,86 & 5,86 & 5,88 & 5,86 & 5,87 \\
\hline 6 & Tempu re.jo & 1,94 & 1,94 & 1,94 & 1,94 & 1,94 \\
\hline 7 & Silo & 5,48 & 5,47 & 5,49 & 5,48 & 5,48 \\
\hline 8 & \begin{tabular}{|l|} 
Mayang \\
\end{tabular} & 0,71 & 0,71 & 0,72 & 0,71 & 0,71 \\
\hline 9 & Mumbul s ari & 0,73 & 0,73 & 0,74 & 0,73 & 0,73 \\
\hline 10 & $\begin{array}{l}\text { Jenggawah } \\
\end{array}$ & 2,84 & 2,84 & 2,85 & 2,84 & 2,84 \\
\hline 11 & \begin{tabular}{|l|} 
A jung \\
\end{tabular} & 1,46 & 1,46 & 1,46 & 1,46 & 1,46 \\
\hline 12 & Rambi pujji & 6,90 & 6,89 & 6,91 & 6,90 & 6,90 \\
\hline 13 & B alung & 5,82 & 5,82 & 5,84 & 5,82 & 5,82 \\
\hline 14 & Umbul s ari & 1,50 & 1,50 & 1,50 & 1,50 & 1,50 \\
\hline 15 & Semboro & $\mathbf{0 , 9 1}$ & $\mathbf{0 , 9 1}$ & 0,91 & 0,91 & $\mathbf{0 , 9 1}$ \\
\hline 16 & \begin{tabular}{|l|} 
Jombang \\
\end{tabular} & 0,34 & 0,34 & 0,34 & 0,34 & 0,34 \\
\hline 17 & Sumber baru & 2,70 & 2,70 & 2,71 & 2,70 & 2,70 \\
\hline 18 & \begin{tabular}{|l|} 
Tanggul \\
\end{tabular} & 2,49 & 2,49 & 2,50 & 2,49 & 2,49 \\
\hline 19 & Bangs al s ari & 9,19 & 9,18 & 9,21 & 9,19 & 9,19 \\
\hline 20 & Panti & 2,37 & 2,47 & 2,37 & 2,37 & 2,40 \\
\hline 21 & Suko rambi & 0,69 & 0,69 & 0,69 & 0,69 & 0,69 \\
\hline 22 & Arjasa & 0,79 & 0,79 & 0,79 & 0,79 & 0,79 \\
\hline 23 & Pakus ari & 0,43 & 0,43 & 0,44 & 0,43 & 0,43 \\
\hline 24 & \begin{tabular}{|l|} 
Kalis at \\
\end{tabular} & 3,95 & 3,95 & 3,96 & 3,95 & 3,95 \\
\hline 25 & Ledok ombo & 1,20 & 1,20 & 1,20 & 1,20 & 1,20 \\
\hline 26 & Sumber jambe & 1,02 & 1,02 & 1,02 & 1,02 & 1,02 \\
\hline 27 & \begin{tabular}{|l|} 
Suko wono \\
\end{tabular} & 1,50 & 1,49 & 1,50 & 1,50 & 1,50 \\
\hline 28 & Jelbuk & 1,27 & 1,27 & 1,28 & 1,27 & 1,28 \\
\hline 29 & Kaliwates & 11,44 & 11,43 & 11,47 & 11,44 & 11,45 \\
\hline 30 & Sumbersari & 5,94 & 5,93 & 5,95 & 5,94 & 5,94 \\
\hline 31 & Patrang & 2,38 & 2,37 & 2,38 & 2,38 & 2,38 \\
\hline & Total & 100,00 & 100,00 & 100,00 & 100,00 & 100,00 \\
\hline
\end{tabular}

Sumber: diolah dari BPS Provinsi Jatim, 2013 
Tabel 5. Kontribusi Sektor Listrik, Gas \& Air Bersih Pada Kecamatan Di Kabupaten Jember Tahun 2008-2011

\begin{tabular}{|c|c|c|c|c|c|c|}
\hline \multicolumn{7}{|c|}{ Kontribusi Sektor Listrik, Gas \& Air Bensih Tahum 2008-2011 } \\
\hline No & Kecamatan & 2008 & 2009 & 2010 & 2011 & Rata-rata \\
\hline 1 & Kencong & 2,40 & 2,41 & 2,41 & 2,41 & 2,41 \\
\hline 2 & Gumuk mas & 3,78 & 3,43 & 3,43 & 3,43 & 3,52 \\
\hline 3 & Puger & 6,24 & 6,26 & 6,26 & 6,26 & 6,25 \\
\hline 4 & Wuiluhan & 6,46 & 6,48 & 6,48 & 6,48 & 6,48 \\
\hline 5 & Ambulu & 5,51 & 5,53 & 5,53 & 5,53 & 5,52 \\
\hline 6 & Tempu rejo & 2,76 & 2,77 & 2,77 & 2,77 & 2,76 \\
\hline 7 & Silo & 5,53 & 5,55 & 5,55 & 5,55 & 5,55 \\
\hline 8 & Mayang & 1,32 & 1,32 & 1,32 & 1,32 & 1,32 \\
\hline 9 & Mumbul sari & 2,08 & 2,09 & 2,09 & 2,09 & 2,08 \\
\hline 10 & Je nggawah & 3,40 & 3,41 & 3,41 & 3,41 & 3,40 \\
\hline 11 & A.jumg & 2,75 & 2,76 & 2,76 & 2,76 & 2,75 \\
\hline 12 & Rambi puji & 3,27 & 3,29 & 3,29 & 3,29 & 3,28 \\
\hline 13 & B alung & 3,30 & 3,31 & 3,31 & 3,31 & 3,31 \\
\hline 14 & Umbul sari & 2,56 & 2,57 & 2,57 & 2,57 & 2,56 \\
\hline 15 & Semboro & 1,06 & 1,07 & 1,07 & 1,07 & 1,07 \\
\hline 16 & Jombang & 1,53 & 1,53 & 1,53 & 1,53 & 1,53 \\
\hline 17 & Sumber baru & 5,02 & 5,04 & 5,04 & 5,04 & 5,03 \\
\hline 18 & Tanggul & 3,59 & 3,60 & 3,60 & 3,60 & 3,60 \\
\hline 19 & Bangs al s ari & 6,51 & 6,53 & 6,53 & 6,53 & 6,53 \\
\hline 20 & Panti & 1,94 & 1,95 & 1,95 & 1,95 & 1,94 \\
\hline 21 & Suko rambi & 0,86 & 0,86 & 0,86 & 0,86 & 0,86 \\
\hline 22 & Arjas a & 0,89 & 0,89 & 0,89 & 0,89 & 0,89 \\
\hline 23 & Pakus ari & 1,02 & 1,02 & 1,02 & 1,02 & 1,02 \\
\hline 24 & Kalis at & 2,84 & 2,85 & 2,85 & 2,85 & 2,85 \\
\hline 25 & Ledok ombo & 2,29 & 2,30 & 2,30 & 2,30 & 2,30 \\
\hline 26 & Sumber jambe & 2,09 & 2,10 & 2,10 & 2,10 & 2,10 \\
\hline 27 & Suko womo & 1,94 & 1,95 & 1,95 & 1,95 & 1,95 \\
\hline 28 & Jelbuk & 0,70 & 0,71 & 0,71 & 0,71 & 0,70 \\
\hline 29 & Kaliwates & 4,83 & 4,85 & 4,85 & 4,85 & 4,84 \\
\hline $\mathbf{3 0}$ & Sumber'sari & 7,34 & 7,37 & 7,37 & 7,37 & 7,36 \\
\hline 31 & Patrang & 4,21 & 4,22 & 4,22 & 4,22 & 4,22 \\
\hline & Total & 100,00 & 100,00 & 100,00 & 100,00 & 100,00 \\
\hline
\end{tabular}

Sumber: diolah dari BPS Provinsi Jatim, 2013

Selanjutnya dapat dijelaskan

atas hasil analisa kontribusi dari

peranan Sektor Bangunan/Konstruksi

pada masing-masing Kecamatan terhadap PDRB atas dasar harga konstan Kabupaten Jember mulai tahun 2008 sampai dengan tahun 2011 dapat dilihat dalam sajian Tabel 6.

Tabel 6. Kontribusi Sektor Bangunan/Konstruksi Pada Kecamatan Di Kabupaten Jember Tahun 2008-2011

\begin{tabular}{|c|c|c|c|c|c|c|}
\hline \multicolumn{7}{|c|}{ Kontribusi Sektor Bangunan/Konstruksi Tahun 2008-2011 } \\
\hline No & Kecamatan & 2008 & 2009 & 2010 & 2011 & Rata-rata \\
\hline 1 & Kencong & 7,95 & 7,95 & 7,95 & 7,95 & 7,95 \\
\hline 2 & Gumuk mas & 2,64 & 2,64 & 2,64 & 2,64 & 2,64 \\
\hline 3 & Puger & 9,56 & $\mathbf{9 , 5 8}$ & 9,58 & 9,58 & 9,57 \\
\hline 4 & Wuluhan & 5,53 & 5,53 & 5,53 & 5,53 & 5,53 \\
\hline 5 & Ambulu & 7,07 & 7,08 & 7,08 & 7,08 & 7,07 \\
\hline 6 & Tempu re jo & 2,45 & 2,46 & 2,46 & 2,46 & 2,46 \\
\hline 7 & Silo & 6,36 & 6,36 & 6,36 & 6,36 & 6,36 \\
\hline 8 & \begin{tabular}{|l|} 
Mayang \\
\end{tabular} & 1,59 & 1,59 & 1,59 & 1,59 & 1,59 \\
\hline 9 & Mumbul sari & 3,12 & 3,13 & 3,13 & 3,13 & 3,13 \\
\hline 10 & Jenggawah & $\mathbf{1 , 5 3}$ & 1,40 & $\mathbf{1 , 4 0}$ & $\mathbf{1 , 4 0}$ & $\mathbf{1 , 4 3}$ \\
\hline 11 & A jung & $\mathbf{1 , 0 2}$ & $\mathbf{1 , 0 2}$ & $\mathbf{1 , 0 2}$ & $\mathbf{1 , 0 2}$ & $\mathbf{1 , 0 2}$ \\
\hline 12 & Rambi puji & 3,03 & 3,03 & 3,03 & 3,03 & $\mathbf{3 , 0 3}$ \\
\hline 13 & B alung & 2,93 & 2,93 & 2,93 & 2,93 & 2,93 \\
\hline 14 & Umbul s ari & 2,17 & 2,17 & 2,17 & $\mathbf{2 , 1 7}$ & 2,17 \\
\hline 15 & Semboro & $\mathbf{0 , 6 2}$ & $\mathbf{0 , 6 2}$ & $\mathbf{0 , 6 2}$ & $\mathbf{0 , 6 2}$ & $\mathbf{0 , 6 2}$ \\
\hline 16 & Jombang & 5,64 & 5,65 & 5,65 & 5,65 & 5,64 \\
\hline 17 & Sumber baru & 4,55 & 4,56 & 4,56 & 4,56 & 4,56 \\
\hline 18 & Tanggul & 1,45 & 1,45 & 1,45 & 1,45 & 1,45 \\
\hline 19 & B angs al sari & 4,40 & 4,41 & 4,41 & 4,41 & 4,40 \\
\hline 20 & Panti & 2,47 & 2,47 & 2,47 & 2,47 & 2,47 \\
\hline 21 & Suko rambi & 1,12 & 1,12 & 1,12 & 1,12 & 1,12 \\
\hline 22 & Arjas a & $\mathbf{0 , 6 9}$ & $\mathbf{0 , 6 9}$ & 0,69 & 0,69 & $\mathbf{0 , 6 9}$ \\
\hline 23 & Pakus ari & 1,94 & 1,95 & 1,95 & 1,95 & 1,95 \\
\hline 24 & Kalis at & 2,24 & 2,24 & 2,24 & 2,24 & 2,24 \\
\hline 25 & Ledok ombo & 2,53 & 2,53 & 2,53 & 2,53 & 2,53 \\
\hline 26 & Sumber jambe & $\mathbf{1 , 8 1}$ & $\mathbf{1 , 8 1}$ & $\mathbf{1 , 8 1}$ & $\mathbf{1 , 8 1}$ & $\mathbf{1 , 8 1}$ \\
\hline 27 & Suko wono & 2,25 & 2,25 & 2,25 & 2,25 & 2,25 \\
\hline 28 & Jelbuk & 0,44 & 0,44 & 0,44 & 0,44 & 0,44 \\
\hline 29 & Kaliwates & 3,10 & 3,10 & 3,10 & 3,10 & 3,10 \\
\hline 30 & Sumber sari & 4,49 & 4,52 & 4,51 & 4,51 & 4,51 \\
\hline \multirow[t]{2}{*}{31} & Patrang & 3,31 & 3,31 & $\mathbf{3 , 3 1}$ & $\mathbf{3 , 3 1}$ & $\mathbf{3 , 3 1}$ \\
\hline & Total & 100,00 & 100,00 & 100,00 & 100,00 & 100,00 \\
\hline
\end{tabular}

Sumber: diolah dari BPS Provinsi Jatim, 2013 
Selanjutnya dapat dijelaskan atas hasil analisa kontribusi dari peranan Sektor Pengangkutan \& Komunikasi pada masing-masing Kecamatan terhadap PDRB atas

Tabel 7. Kontribusi Sektor Pengangkutan \& Komunikasi Pada Kecamatan Di Kabupaten Jember Tahun 2008-2011

\begin{tabular}{|c|c|c|c|c|c|c|}
\hline \multicolumn{7}{|c|}{ Kontribusi Sektor Pengangkutan \& Komunikasi Tahum 2008-2011 } \\
\hline No & \begin{tabular}{|l|} 
Kecamatan \\
\end{tabular} & 2008 & 2009 & 2010 & 2011 & Rata-rata \\
\hline 1 & Kencong & 2,44 & 2,44 & 2,44 & 2,44 & 2,44 \\
\hline 2 & Gumuk mas & 2,21 & 2,21 & 2,21 & 2,21 & 2,21 \\
\hline 3 & Puger & 3,48 & 3,47 & 3,48 & 3,48 & 3,47 \\
\hline 4 & Wuluhan & 3,41 & 3,41 & 3,41 & 3,41 & 3,41 \\
\hline 5 & Ambulu & 5,91 & 5,90 & 5,91 & 5,91 & 5,90 \\
\hline 6 & Tempu rejo & 1,61 & 1,61 & 1,61 & 1,61 & 1,61 \\
\hline 7 & Silo & 4,51 & 4,50 & 4,51 & 4,51 & 4,51 \\
\hline 8 & \begin{tabular}{|l|} 
Mayang \\
\end{tabular} & 0,68 & 0,68 & 0,68 & 0,68 & 0,68 \\
\hline 9 & Mumbul sari & 0,60 & 0,60 & 0,60 & 0,60 & 0,60 \\
\hline 10 & \begin{tabular}{|l|} 
Jenggawah \\
\end{tabular} & 2,79 & 2,79 & 2,79 & 2,79 & 2,79 \\
\hline 11 & A.jung & 0,87 & 0,86 & 0,86 & 0,86 & 0,86 \\
\hline 12 & Rambi pují & 5,07 & 5,06 & 5,07 & 5,07 & 5,06 \\
\hline 13 & B alung & 3,75 & 3,75 & 3,75 & 3,75 & 3,75 \\
\hline 14 & Umbul sari & 1,43 & 1,42 & 1,43 & 1,43 & 1,42 \\
\hline 15 & Semboro & 0,61 & $\mathbf{0 , 6 1}$ & 0,61 & 0,61 & $\mathbf{0 , 6 1}$ \\
\hline 16 & \begin{tabular}{|l|} 
Jombang \\
\end{tabular} & 0,45 & 0,45 & 0,45 & 0,45 & 0,45 \\
\hline 17 & \begin{tabular}{|l|} 
Sumber baru \\
\end{tabular} & 1,94 & 1,93 & 1,94 & 1,94 & 1,93 \\
\hline 18 & \begin{tabular}{|l|} 
Tanggul \\
\end{tabular} & 5,67 & 5,66 & 5,67 & 5,67 & 5,67 \\
\hline 19 & \begin{tabular}{|l} 
B angs al sari \\
\end{tabular} & 2,56 & 2,55 & 2,56 & 2,56 & 2,56 \\
\hline 20 & \begin{tabular}{|l|} 
Panti \\
\end{tabular} & 0,48 & 0,47 & 0,48 & 0,48 & 0,48 \\
\hline 21 & Suko rambi & 0,27 & 0,27 & 0,27 & 0,27 & 0,27 \\
\hline 22 & \begin{tabular}{|l|} 
Arjas a \\
\end{tabular} & 1,87 & 1,87 & 1,87 & 1,87 & 1,87 \\
\hline 23 & Pakusari & 0,25 & 0,25 & 0,25 & 0,25 & 0,25 \\
\hline 24 & \begin{tabular}{|l|} 
Kalis at \\
\end{tabular} & 4,78 & 4,77 & 4,78 & 4,78 & 4,78 \\
\hline 25 & Ledok ombo & 1,37 & 1,36 & 1,37 & 1,37 & 1,37 \\
\hline 26 & \begin{tabular}{|l|} 
Sumber jambe \\
\end{tabular} & 0,16 & 0,16 & 0,16 & 0,16 & 0,16 \\
\hline 27 & \begin{tabular}{|l|} 
Suko wono \\
\end{tabular} & 1,67 & 1,67 & 1,67 & 1,67 & 1,67 \\
\hline 28 & \begin{tabular}{|l|} 
Jelbuk \\
\end{tabular} & 0,24 & 0,24 & 0,24 & 0,24 & 0,24 \\
\hline 29 & Kaliwates & 7,84 & 7,83 & 7,84 & 7,84 & 7,83 \\
\hline 30 & Sumber sari & 10,26 & 10,24 & 10,26 & 10,26 & 10,25 \\
\hline 31 & Patrang & 20,84 & 20,96 & 20,84 & 20,84 & 20,87 \\
\hline & $\begin{array}{r}\text { Total } \\
\text { Tot }\end{array}$ & 100,00 & 100,00 & 100,00 & 100,00 & 100,00 \\
\hline
\end{tabular}

Sumber: diolah dari BPS Provinsi Jatim, 2013

Selanjutnya dapat dijelaskan atas hasil analisa kontribusi dari peranan Sektor Perdagangan, Hotel \& Restoran pada masing-masing Kecamatan terhadap PDRB atas dasar harga konstan di Kabupaten Jember mulai tahun 2008 sampai dengan tahun 2011 dalam sajian Tabel 8. dasar harga konstan di Kabupaten Jember mulai tahun 2008 sampai dengan tahun 2011 dapat dilihat dalam sajian Tabel 7. 
Tabel 8. Kontribusi Sektor Perdagangan, Hotel \& Restoran Pada Kecamatan Di Kabupaten Jember Tahun 2008-2011

\begin{tabular}{|c|c|c|c|c|c|c|}
\hline \multicolumn{7}{|c|}{ Kontribusi Sektor Perdagangan, Hotel \& Restoran Tahun 2008-2011 } \\
\hline No & Kecamatan & 2008 & 2009 & 2010 & 2011 & Rata-rata \\
\hline 1 & Kencong & 0,37 & 0,37 & 0,37 & 0,41 & $\mathbf{0 , 3 8}$ \\
\hline 2 & Gumuk mas & $\mathbf{0 , 9 1}$ & $\mathbf{0 , 9 1}$ & $\mathbf{0 , 9 1}$ & $\mathbf{1 , 0 2}$ & 0,94 \\
\hline 3 & Puger & 5,07 & 5,07 & 5,07 & 5,63 & 5,21 \\
\hline 4 & Wuluhan & 3,95 & 3,95 & 3,95 & 4,40 & 4,06 \\
\hline 5 & Ambulu & 2,38 & 2,38 & 2,38 & 2,65 & 2,45 \\
\hline 6 & Tempu re.jo & 0,63 & 0,63 & 0,63 & 0,70 & 0,65 \\
\hline$\frac{0}{7}$ & Silo & 0,92 & 0,92 & 0,93 & $1, \mathbf{O 2}$ & 0,94 \\
\hline 8 & Mayang & 0,95 & 0,95 & 0,95 & 1,05 & 0,97 \\
\hline 9 & Mumbul sari & 0,30 & 0,30 & $\mathbf{0 , 3 0}$ & 0,33 & 0,31 \\
\hline 10 & Jenggawah & 0,98 & 0,98 & 0,98 & 1,09 & 1,01 \\
\hline 11 & A.jung & 1,86 & 1,86 & 1,86 & 2,07 & 1,91 \\
\hline 12 & Rambi puji & 2,54 & 2,54 & 2,54 & 2,82 & 2,61 \\
\hline 13 & B alung & 1,35 & 1,35 & 1,35 & 1,50 & 1,38 \\
\hline 14 & Umbul sari & 0,66 & 0,66 & 0,66 & 0,74 & 0,68 \\
\hline 15 & \begin{tabular}{|l|} 
Semboro \\
\end{tabular} & 0,52 & 0,52 & 0,52 & 0,58 & 0,53 \\
\hline 16 & \begin{tabular}{|l|} 
Jombang \\
\end{tabular} & 0,15 & 0,15 & 0,15 & 0,17 & 0,16 \\
\hline 17 & \begin{tabular}{|l} 
Sumber baru \\
\end{tabular} & 4,02 & 4,02 & 4,02 & $\mathbf{4 , 4 7}$ & 4,13 \\
\hline 18 & Tanggul & 1,63 & 1,63 & 1,63 & 1,81 & 1,68 \\
\hline 19 & B angs al sari & 2,08 & 2,08 & 2,08 & 2,31 & 2,14 \\
\hline 20 & Panti & 0,31 & 0,31 & 0,31 & 0,35 & 0,32 \\
\hline 21 & Suko rambi & 0,36 & 0,36 & 0,36 & 0,40 & 0,37 \\
\hline 22 & Arjas a & 0,43 & 0,43 & 0,43 & 0,48 & 0,44 \\
\hline 23 & Pakusari & 0,45 & 0,45 & 0,45 & 0,50 & 0,46 \\
\hline 24 & \begin{tabular}{|l|} 
Kalis at \\
\end{tabular} & 0,84 & 0,84 & 0,84 & 0,93 & 0,86 \\
\hline 25 & Ledok ombo & 0,44 & 0,44 & 0,44 & 0,49 & 0,46 \\
\hline 26 & Sumber jambe & 0,07 & 0,07 & 0,07 & 0,08 & 0,07 \\
\hline 27 & \begin{tabular}{|l|} 
Suko wono \\
\end{tabular} & 1,95 & 1,95 & 1,95 & 2,16 & 2,00 \\
\hline 28 & Jelbuk & 0,09 & 0,09 & 0,09 & 0,10 & 0,09 \\
\hline 29 & Kaliwates & 23,03 & 23,03 & 23,03 & 25,60 & 23,67 \\
\hline 30 & Sumber sari & 27,59 & 27,59 & 27,59 & 19,51 & 25,57 \\
\hline \multirow[t]{2}{*}{31} & Patrang & 13,17 & 13,17 & 13,17 & 14,64 & 13,54 \\
\hline & Total & 100,00 & 100,00 & 100,00 & 100,00 & 100,00 \\
\hline
\end{tabular}

Tabel 9. Kontribusi Sektor Keuangan, Persewaan \& Jasa Perusahaan Pada Kecamatan Di Kabupaten Jember Tahun 2008-2011

\begin{tabular}{|c|c|c|c|c|c|c|}
\hline \multicolumn{7}{|c|}{ Kontribusi Sektor Keuangan, Persewaan \& Jasa Perusahaan Tahun $2008-2011$} \\
\hline No & Ke camatan & 2008 & 2009 & 2010 & 2011 & Rata-rata \\
\hline $\mathbf{1}$ & Kencong & 2,30 & 2,40 & 2,40 & 2,40 & 2,38 \\
\hline 2 & Gumuk mas & 1,73 & 1,80 & 1,80 & 1,80 & 1,78 \\
\hline 3 & Puger & 2,39 & 2,49 & 2,49 & 2,49 & 2,47 \\
\hline 4 & Wuluhan & 3,45 & 3,60 & 3,60 & 3,60 & 3,56 \\
\hline 5 & Ambulu & 3,02 & 3,15 & 3,15 & 3,15 & 3,11 \\
\hline 6 & Tempu rejo & 1,58 & 1,65 & 1,65 & 1,65 & 1,63 \\
\hline 7 & Silo & 2,18 & 2,28 & 2,28 & 2,28 & 2,25 \\
\hline 8 & Mayang & $\mathbf{0 , 5 0}$ & 0,53 & 0,53 & 0,53 & 0,52 \\
\hline 9 & Mumbul sari & 0,96 & $\mathbf{1 , 0 0}$ & $\mathbf{1 , 0 0}$ & $\mathbf{1 , 0 0}$ & $\mathbf{0 , 9 9}$ \\
\hline 10 & Jenggawah & 1,63 & 1,70 & 1,70 & 1,70 & 1,68 \\
\hline 11 & Ajung & 2,17 & 2,26 & 2,26 & 2,26 & 2,24 \\
\hline 12 & Rambi puji & 3,98 & 2,35 & 2,35 & 2,35 & 2,76 \\
\hline 13 & Balung & 1,83 & 1,91 & 1,91 & 1,91 & 1,89 \\
\hline 14 & Umbul s ari & 1,55 & 1,61 & 1,61 & 1,61 & 1,59 \\
\hline 15 & Semboro & 0,92 & 0,96 & 0,96 & 0,96 & 0,95 \\
\hline 16 & \begin{tabular}{|l|} 
Jombang \\
\end{tabular} & 1,23 & 1,28 & 1,28 & 1,28 & 1,27 \\
\hline 17 & Sumber baru & 2,61 & 2,72 & 2,72 & 2,72 & 2,70 \\
\hline 18 & \begin{tabular}{|l|} 
Tanggul \\
\end{tabular} & 4,46 & 2,22 & 2,22 & 2,22 & 2,78 \\
\hline 19 & Bangs al sari & 3,57 & 3,72 & 3,72 & 3,72 & 3,68 \\
\hline 20 & Panti & 2,23 & 2,32 & 2,32 & 2,32 & 2,30 \\
\hline 21 & Suko rambi & $\mathbf{0 , 6 1}$ & 0,64 & 0,64 & 0,64 & 0,63 \\
\hline 22 & Arjas a & 0,58 & $\mathbf{0 , 6 1}$ & $\mathbf{0 , 6 1}$ & $\mathbf{0 , 6 1}$ & $\mathbf{0 , 6 0}$ \\
\hline 23 & \begin{tabular}{|l|} 
Pakus ari \\
\end{tabular} & 0,65 & 0,68 & 0,68 & 0,68 & 0,67 \\
\hline 24 & Kalis at & 1,23 & 1,29 & 1,29 & 1,29 & 1,27 \\
\hline 25 & Ledok ombo & 0,96 & $\mathbf{1 , 0 1}$ & $\mathbf{1 , 0 1}$ & $\mathbf{1 , 0 1}$ & $\mathbf{1 , 0 0}$ \\
\hline 26 & Sumber jambe & 0,87 & $\mathbf{0 , 9 1}$ & $\mathbf{0 , 9 1}$ & $\mathbf{0 , 9 1}$ & $\mathbf{0 , 9 0}$ \\
\hline 27 & Suko wono & 1,16 & 1,20 & 1,20 & 1,20 & 1,19 \\
\hline 28 & Jelbuk & 0,36 & $\mathbf{0 , 3 8}$ & $0, \mathbf{3 8}$ & $\mathbf{0 , 3 8}$ & $\mathbf{0 , 3 7}$ \\
\hline 29 & Kaliwates & 25,14 & 26,20 & 26,20 & 26,20 & 25,93 \\
\hline 30 & Sumber sari & 16,12 & 16,80 & 16,80 & 16,80 & 16,63 \\
\hline 31 & \begin{tabular}{|l|} 
Patrang \\
\end{tabular} & 8,00 & 8,34 & 8,34 & 8,34 & 8,25 \\
\hline & \begin{tabular}{|l} 
Total \\
\end{tabular} & 100,00 & 100,00 & 100,00 & 100,00 & 100,00 \\
\hline
\end{tabular}

Selanjutnya dapat dijelaskan atas hasil analisa kontribusi dari peranan Sektor Jasa-jasa pada masing-masing Kecamatan terhadap
PDRB atas dasar harga konstan di Kabupaten Jember mulai dari tahun 2008 sampai dengan tahun 2011 dapat dilihat dalam sajian Tabel 10 . 
Tabel 10. Kontribusi Sektor Jasa-jasa Pada Kecamatan Di Kabupaten Jember Tahun 20082011

\begin{tabular}{|c|c|c|c|c|c|c|}
\hline \multicolumn{7}{|c|}{ Kontribusi Sektor Jasa-jasa Tahum 2008-2011 } \\
\hline No & Kecamatan & 2008 & 2009 & 2010 & 2011 & Rata-rata \\
\hline 1 & Kencong & 2,65 & 2,65 & 2,65 & 2,65 & 2,65 \\
\hline 2 & Gumuk mas & 2,65 & 2,65 & 2,65 & 2,65 & 2,65 \\
\hline 3 & Puger & 4,81 & 4,81 & 4,81 & 4,81 & 4,81 \\
\hline 4 & Wuluhan & 5,43 & 5,43 & 5,43 & 5,43 & 5,43 \\
\hline 5 & Ambulu & 9,22 & 9,22 & 9,22 & 9,22 & 9,22 \\
\hline 6 & Tempu rejo & 1,70 & 1,70 & 1,70 & 1,70 & 1,70 \\
\hline 7 & Silo & 3,20 & 3,20 & 3,20 & 3,20 & 3,20 \\
\hline 8 & \begin{tabular}{|l|} 
Mayang \\
\end{tabular} & 0,65 & 0,65 & 0,65 & 0,65 & 0,65 \\
\hline 9 & Mumbul sari & 0,96 & 0,96 & 0,96 & 0,96 & 0,96 \\
\hline 10 & Jenggawah & 2,35 & 2,36 & 2,35 & 2,35 & 2,35 \\
\hline 11 & Ajung & 1,14 & 1,14 & 1,14 & 1,14 & 1,14 \\
\hline 12 & Rambi puji & 2,69 & 2,69 & 2,69 & 2,69 & 2,69 \\
\hline 13 & B alung & 4,23 & 4,23 & 4,23 & 4,23 & 4,23 \\
\hline 14 & Umbul s ari & 2,31 & 2,31 & 2,31 & 2,31 & 2,31 \\
\hline 15 & Semboro & 0,84 & 0,84 & 0,84 & 0,84 & 0,84 \\
\hline 16 & \begin{tabular}{|l|} 
Jombang \\
\end{tabular} & 1,47 & 1,47 & 1,47 & 1,47 & 1,47 \\
\hline 17 & Sumber baru & 1,89 & 1,89 & 1,89 & 1,89 & 1,89 \\
\hline 18 & \begin{tabular}{|l|} 
Tanggul \\
\end{tabular} & 3,47 & 3,47 & 3,47 & 3,47 & 3,47 \\
\hline 19 & Bangsal sari & 3,95 & 3,95 & 3,95 & 3,95 & 3,95 \\
\hline 20 & Panti & 1,04 & 1,04 & 1,04 & $\mathbf{1 , 0 4}$ & $\mathbf{1 , 0 4}$ \\
\hline 21 & Suko rambi & 0,62 & 0,62 & 0,62 & 0,62 & 0,62 \\
\hline 22 & Arjas a & 0,68 & 0,68 & 0,68 & 0,68 & 0,68 \\
\hline 23 & Pakus ari & 0,45 & 0,45 & 0,45 & 0,45 & 0,45 \\
\hline 24 & Kalis at & 2,23 & 2,23 & 2,23 & 2,23 & 2,23 \\
\hline 25 & Ledok ombo & 0,77 & 0,77 & 0,77 & 0,77 & 0,77 \\
\hline 26 & Sumber jambe & 0,79 & 0,79 & 0,79 & 0,79 & 0,79 \\
\hline 27 & Suko wono & $\mathbf{0 , 9 0}$ & $\mathbf{0 , 9 0}$ & $\mathbf{0 , 9 0}$ & $\mathbf{0 , 9 0}$ & $\mathbf{0 , 9 0}$ \\
\hline 28 & Jelbuk & $\mathbf{0 , 2 8}$ & $\mathbf{0 , 2 8}$ & $\mathbf{0 , 2 8}$ & 0,28 & 0,28 \\
\hline 29 & Kaliwates & 12,77 & 12,77 & 12,77 & 12,77 & 12,77 \\
\hline 30 & Sumber sari & $\mathbf{8 , 5 8}$ & $\mathbf{8 , 5 8}$ & $\mathbf{8 , 5 8}$ & $\mathbf{8 , 5 8}$ & $\mathbf{8 , 5 8}$ \\
\hline 31 & Patrang & 15,27 & 15,27 & 15,27 & 15,27 & 15,27 \\
\hline & Total & 100,00 & 100,00 & 100,00 & 100,00 & 100,00 \\
\hline
\end{tabular}

Hasil analisis PDRB per kapita dan pertumbuhan PDRB pada masing-masing Kecamatan di Kabupaten Jember selama kurun waktu tahun 2008-2011, beserta rataratanya untuk seluruh Kecamatan di Kabupaten Jember, dapat dilihat pada Tabel 11.

Berdasarkan sajian hasil analisis mengunakan metode Tipologi Klassen pada Tabel 11 diatas menunjukkan bahwa pola pertumbuhan ekonomi pada masingmasing Kecamatan di Kabupaten Jember selama tahun 2008 sampai tahun 2011 dapat diketahui kriteria klasifikasi pola pertumbuhan ekonomi diantara tiga puluh satu Kecamatan di Kabupaten Jember yang dijelaskan sebagai berikut: Pertama, Klasifikasi 1: Daerah cepat maju dan cepat tumbuh, daerah yang memiliki tingkat pertumbuhan ekonomi dan pendapatan per kapita yang lebih tinggi dibandingkan ratarata Kecamatan di Kabupaten Jember. Maka dari hasil analisis yang disajikan pada Tabel 11 diatas terdiri dari 8 Daerah Kecamatan yaitu: Puger, Wuluhan, Ambulu, Silo, 
Sumberbaru, Bangsalsari, Kaliwates

dan Patrang.

Tabel 11. Klasifikasi Tipologi Klassen Pada Kecamatan Di Kabupaten Jember Tahun 20082011

\begin{tabular}{|c|c|c|c|c|}
\hline \multicolumn{5}{|c|}{ Klasifikasi Tipologi Klassen Kecamatan Di Kabupaten Jember Tahun 2008-2011 } \\
\hline No & Kecamatan & PDRB Perkapita & Growth & Tipologi Klassen \\
\hline 1 & Kencong & Rendah & Rendah & Te rbelakang \\
\hline 2 & Gumuk mas & Rendah & Tinggi & Be rkembang Ce pat \\
\hline 3 & Puger & Tinggi & Tinggi & Ce pat Maju dan Tumbuh \\
\hline 4 & Wuluhan & Tinggi & Tinggi & Ce pat Maju dan Tumbuh \\
\hline 5 & Ambulu & Tinggi & Tinggi & Cepat Maju dan Tumbuh \\
\hline 6 & Tempu rejo & Rendah & Rendah & Te rbelakang \\
\hline 7 & Silo & Tinggi & Tinggi & Cepat Maju dan Tumbuh \\
\hline 8 & Mayang & Rendah & Tinggi & Berkembang Cepat \\
\hline 9 & Mumbul sari & Rendah & Rendah & Te rbelakang \\
\hline 10 & Jenggawah & Rendah & Tinggi & Berkembang Ce pat \\
\hline 11 & A jung & Rendah & Rendah & Te rbelakang \\
\hline 12 & Rambi puji & Tinggi & Rendah & Maju Tertekan \\
\hline 13 & B alung & Rendah & Tinggi & Berkembang Ce pat \\
\hline 14 & Umbul sari & Rendah & Rendah & Te rbelakang \\
\hline 15 & Semboro & Rendah & Rendah & Te rbelakang \\
\hline 16 & Jombang & Rendah & Tinggi & Berkembang Cepat \\
\hline 17 & Sumber baru & Tinggi & Tinggi & Ce pat Maju dan Tumbuh \\
\hline 18 & Tanggul & Tinggi & Rendah & Maju Tertekan \\
\hline 19 & B angs al sari & Tinggi & Tinggi & Cepat Maju dan Tumbuh \\
\hline 20 & Panti & Rendah & Rendah & Te rbelakang \\
\hline 21 & Suko rambi & Rendah & Tinggi & Berkembang Ce pat \\
\hline 22 & Arjas a & Rendah & Tinggi & Berkembang Ce pat \\
\hline 23 & Pakus ari & Rendah & Tinggi & Berkembang Ce pat \\
\hline 24 & Kalis at & Rendah & Tinggi & Berkembang Ce pat \\
\hline 25 & Ledok ombo & Rendah & Tinggi & Berkembang Ce pat \\
\hline 26 & Sumber jambe & Rendah & Rendah & Te rbelakang \\
\hline 27 & Suko wono & Rendah & Tinggi & Berkembang Cepat \\
\hline 28 & Jelbuk & Rendah & Tinggi & Berkembang Ce pat \\
\hline 29 & Kaliwates & Tinggi & Tinggi & Cepat Maju dan Tumbuh \\
\hline 30 & Sumber sari & Tinggi & Rendah & Maju Te rtekan \\
\hline 31 & Patrang & Tinggi & Tinggi & Cepat Maju dan Tumbuh \\
\hline
\end{tabular}

\section{Kedua, Klasifikasi 2: Daerah}

maju tapi tertekan, daerah yang memiliki perdapatan perkapita lebih tinggi, tetapi tingkat pertumbuhan ekonominya lebih rendah dibandingkan rata-rata Kabupaten Jember. Maka dari hasil analisis yang disajikan pada Tabel 4.11 diatas terdiri dari 3 Daerah Kecamatan yaitu: Rambi puji, Tanggul, Sumbersari. Ketiga, Klasifikasi 3: Daerah berkembang cepat adalah daerah yang memiliki tingkat pertumbuhan ekonomi tinggi, tetapi tingkat pendapatan perkapita lebih rendah dibanding rata-rata Kabupaten Jember. Maka dari hasil analisis yang disajikan pada Tabel 4.11 diatas terdiri dari 12 Daerah Kecamatan yaitu: Gumukmas, Mayang, Jenggawah, Balung, Jombang, Sukorambi, Arjasa, Pakusari, Kalisat, Ledokombo, Sukowono dan Jelbuk.

Keempat, Klasifikasi 4: Daerah relatif tertinggal adalah 
daerah yang memiliki tingkat pertumbuhan ekonomi dan pendapatan perkapita yang lebih rendah di bandingkan rata-rata Kabupaten Jember. Maka dari hasil analisis yang disajikan pada Tabel 4.11 diatas terdiri dari 8 Daerah Kecamatan yaitu: Kencong, Tempurejo, Mumbulsari, Ajung, Umbulsari, Semboro, Panti dan Sumber jambe.
Hasil analisis menggunakan metode Indeks Williamson yang dapat diklasifikasikan berurutan berdasarkan mulai dari nilai ranking hasil Indeks Williamson tertinggi sampai terendah pada masing-masing Kecamatan di Kabupaten Jember selama kurun waktu tahun 2008 sampai tahun 2011, beserta rataratanya untuk seluruh Kecamatan di Kabupaten Jember. Maka dapat dilihat pada Tabel 12 .

Tabel 12. Ranking Hasil Indeks Williamson Pada Kecamatan Di Kabupaten Jember Tahun 2008-2011

\begin{tabular}{|c|c|c|c|c|c|c|}
\hline \multicolumn{7}{|c|}{ Ranking Indeks Williamson } \\
\hline No & Kecamatan & 2008 & 2009 & 2010 & 2011 & Average \\
\hline 1 & Mumbul sari & 0.16 & 0.17 & 0.16 & 0.15 & 0.16 \\
\hline 2 & Pakus ari & 0.17 & $\mathbf{0 . 1 7}$ & $\mathbf{0 . 1 7}$ & $\mathbf{0 . 1 2}$ & 0.16 \\
\hline 3 & Jombang & 0.15 & 0.15 & 0.15 & 0.14 & 0.15 \\
\hline 4 & Kaliwates & 0.13 & $\mathbf{0 . 1 3}$ & 0.14 & 0.19 & 0.15 \\
\hline 5 & Arjasa & 0.14 & 0.14 & 0.14 & $\mathbf{0 . 1 3}$ & 0.14 \\
\hline 6 & Jelbuk & $\mathbf{0 . 1 4}$ & $\mathbf{0 . 1 5}$ & $\mathbf{0 . 1 5}$ & $\mathbf{0 . 1 1}$ & $\mathbf{0 . 1 4}$ \\
\hline 7 & Sumber sari & $\mathbf{0 . 1 2}$ & $\mathbf{0 . 1 3}$ & $\mathbf{0 . 0 8}$ & $\mathbf{0 . 2 5}$ & $\mathbf{0 . 1 4}$ \\
\hline 8 & Mayang & $\mathbf{0 . 1 3}$ & $\mathbf{0 . 1 3}$ & $\mathbf{0 . 1 3}$ & $\mathbf{0 . 1 3}$ & $\mathbf{0 . 1 3}$ \\
\hline 9 & Suko rambi & 0.14 & 0.14 & 0.14 & $\mathbf{0 . 1 2}$ & $\mathbf{0 . 1 3}$ \\
\hline 10 & Sumber jambe & 0.12 & 0.12 & 0.12 & $\mathbf{0 . 1 5}$ & $\mathbf{0 . 1 3}$ \\
\hline 11 & A.jung & O.10 & O.10 & 0.11 & 0.17 & 0.12 \\
\hline 12 & Patrang & 0.10 & 0.10 & 0.11 & 0.18 & 0.12 \\
\hline 13 & Puger & 0.07 & 0.07 & 0.08 & 0.20 & 0.11 \\
\hline 14 & Tempu rejo & O.10 & O.10 & 0.09 & 0.16 & O.11 \\
\hline 15 & Jenggawah & 0.099 & 0.099 & 0.08 & 0.17 & 0.11 \\
\hline 16 & Ledok ombo & 0.10 & 0.10 & 0.10 & 0.15 & 0.11 \\
\hline 17 & Ambulu & 0.06 & O.06 & 0.07 & 0.20 & 0.10 \\
\hline 18 & Kalis at & 0.07 & 0.07 & 0.06 & 0.16 & 0.09 \\
\hline 19 & Suko wono & 0.07 & 0.07 & 0.06 & 0.15 & 0.09 \\
\hline 20 & Umbul s ari & 0.05 & 0.05 & 0.05 & 0.17 & 0.08 \\
\hline 21 & Semboro & 0.07 & 0.07 & 0.07 & 0.13 & O.08 \\
\hline 22 & Gumuk mas & 0.04 & 0.04 & 0.04 & 0.17 & 0.07 \\
\hline 23 & Wuluhan & O.03 & 0.03 & 0.03 & 0.21 & 0.07 \\
\hline 24 & B alung & 0.04 & 0.04 & 0.03 & 0.17 & 0.07 \\
\hline 25 & B angs al s ari & O.02 & O.02 & 0.03 & 0.20 & 0.07 \\
\hline 26 & Silo & O.01 & O.01 & O.01 & 0.19 & 0.06 \\
\hline 27 & Sumber baru & O.01 & O.01 & O.01 & 0.19 & 0.06 \\
\hline 28 & Panti & 0.04 & 0.04 & 0.04 & 0.15 & O.06 \\
\hline 29 & Kencong & 0.02 & 0.02 & 0.02 & 0.15 & 0.05 \\
\hline 30 & Tanggul & O.01 & O.01 & O.01 & 0.18 & 0.05 \\
\hline 31 & Rambi puji & O.00 & O.00 & $\mathbf{0 . 0 0}$ & $\mathbf{0 . 1 7}$ & 0.04 \\
\hline A & verage Kab J ember & 0.08 & 0.08 & 0.08 & 0.16 & 0.10 \\
\hline
\end{tabular}

Sumber: diolah dari BPS Provinsi Jatim, 2013 
KESIMPULAN

Berdasarkan hasil penelitian

ini, Pemerintah Kabupaten Jember maupun semua elemen masyarakat diharapkan untuk mengatasi dan mengurangi disparitas pendapatan yang sangat tinggi antar Kecamatan di Kabupaten Jember. Maka harus adanya kinerja dan peran dari adanya intervensi Pemerintah Daerah untuk meningkatkan evaluasi dalam sasaran pembangunan perekonomian secara efektif, sebagai aktor utama implementor dan pemangku program-program kebijakan dalam mencapai sasaran dalam terwujudnya determinasi pembangunan ekonomi yang insentif.

Selanjutnya untuk Pemerintah daerah Kabupaten Jember maupun pemerintah daerah tingkat I Provinsi Jawa Timur diharapkan untuk lebih memaksimalkan pengelolaan dan penanganan potensi sektor-sektor perekonomian dengan meningkatkan peran kinerja pemerintah sebagai aktor dan implementor untuk mengimplementasikan kebijakan yang diformulasikan dengan tepat sasaran untuk kepentingan masyarakat dalam segala aktivitas ekonomi sesuai dengan prinsip
Goodgovernance

untuk

meningkatkan

produktifitasnya

sektor ekonomi yang berpotensi dan dapat menanggulangi terjadinya disparitas pendapatan perkapita pada masing-masing Kecamatan di Kabupaten Jember yang sangat tinggi dan memformulasikan sasaran kebijakan yang inklusif dalam upaya mengurangi disparitas pendapatan atau tingkat kesenjangan yang sangat tinggi antar Kecamatan di Kabupaten Jember.

\section{DAFTAR PUSTAKA}

Abdul Hakim, 2002, Ekonomi Pembangunan, Edisi Pertama, Cetakan Pertama, Penerbit, Ekonisia: Yogyakarta.

Arsyad, Lincolin, 1999, Ekonomi Pembangunan; Edisi Keempat, PB STIE YKPN, Yogyakarta.

Arsyad, Lincolin, 2004, Ekonomi Pembangunan;

Edisi Keempat, Bagian Penerbit Sekolah Tinggi Ilmu Ekonomi YKPN, Yogyakarta.

Aswandi, H dan Kuncoro, Mudrajad. 2002. Evaluasi Penetapan Kawasan Andalan: Studi Empiris Di Kalimantan Selatan 1993-1999. Jurnal Ekonomi dan Bisnis Indonesia, Vol. 17, No. 1, 2002, $27-45$. 
2003. Metode Riset untuk Bisnis dan Ekonomi, Erlangga, Jakarta

Auliyaur Rahman, 2010, Analisa Potensi Ekonomi Sektoral Pada Empat Kabupaten di Pulau Madura, Skripsi Universitas Muhammadiyah Malang, Tidak Dipublikasikan.

Blakely, E. J. 1989. Planning Local Economic Development: Theory and Practice. California: SAGE.

Boediono. 1992. Teori Pertumbuhan Ekonomi. Edisi 1. Yogyakarta: BPFE.

Boediono, Publication, Inc, 1981, Teori Pertumbuhan Ekonomi, PB Fakultas Ekonomi UGM, Yogyakarta.

Firman Fandi Liswandana, 2010, Analisis Pertumbuhan Ekonomi dan Sektor Unggulan Antar Kecamatan di Kabupaten Jember Tahun 2005-2008, Skripsi Universitas Muhammadiyah Malang, Tidak Dipublikasikan.

Husaini Usman dan R. Purnomo Setiadi Akbar, 2003, Pengantar Statistika, Bumi Aksara, Jakarta.

Irawan dan Suparmoko, 1987, Ekonomi Pembangunan, Edisi Keempat, Cetakan Pertama, Penerbit: Liberty: Yogyakarta.
Kunarjo, 1997, Perencanaan dan Pembiayaan Pembangunan; Edisi ketiga, UI Pres, Jakarta.

Lincolin Arsyad, 1997, Ekonomi Pembangunan, Edisi Ketiga, Penerbit: STIE YKPN: Yogyakarta.

Pembangunan, 1999, Ekonomi Keempat, Bagian Penerbitan STIE YKPN: Yogyakarta.

Masri Singarimbun dan Sofian Effendi, 1995, Metode Penelitian Survei. Edisi Revisi, Jakarta: LP3S.

Majidi, N. 1997. Anggaran Pembangunan dan Ketimpangan Ekonomi antar Daerah. Prisma, LP3S.

Mudrajad Kuncoro, 1997, Ekonomi Pembangunan, Teori Masalah dan Kebijakan, UPPAMP YKPN, Yogyakarta.

Mudrajad Kuncoro, 2002, Analisis Spasial dan Regional, Studi Aglomerasi dan Kluster Industri Indonesia, UPP AMP YKPN, Yogyakarta.

Mudrajad Kuncoro, 2004, Otonomi dan Pembangunan Daerah: Reformasi, Perencanaan, Strategi, dan Peluang, Penerbit Erlangga, Jakarta.

Nugroho, T. 2004. Disparitas Pembangunan Wilayah Pesisir Utara dan Selatan Jawa Barat (Studi Kasus di Kabupaten Karawang, Subang, Garut dan Ciamis) [Tesis]. Institut Pertanian 
Bogor, Fakultas Ekonomi dan Manajemen. Sekolah Pasca Sarjana. Bogor.

Prasetyo Soepono, 2000, Model Gravitasi Sebagai Alat Pengukur Hinterland dari Central Place, Suatu Kajian Teoritik, JEBI Vol. 15 No. 4, Fakultas Ekonomi, Universitas Gajah Mada, Yogyakarta.

Prasetyo Soepono, 2001, Teori Pertumbuhan Berbasis Ekonomi (Ekspor): Posisi dan sumbangannya Bagiambunan, T.H. Tulus, 2001. Transformasi Perbendaharaan Alat - Alat Analisis Regional, JEBI Vol.16 No. 1, Fakultas Ekonomi, Universitas GajaTarigan, R. Ekonomi Regional Teori dan Mada, Yogyakarta.

Singgih Santoso \& Fandy Tjiptond,odaro, Michael, 2000, Pembangunan 2000, Riset Pemasaran Ekonomi di Dunia Ketiga, Edisi Konsep dan Aplikasi dengan Ketujuh, Penerbit Erlangga: Jakarta. SPSS, PT. Gramedia, JakartaTodaro, MP dan Smith, Stephen C, 2004,

Sjafrizal, Ekonomi Regional Teori dan Aplikasi, Baduose Mediąulus 2008. Padang.

Sofwin Hardiati, Analisis Pertumbuhan Ekonomi Propinsi Jawa Tengah, Tesis MIESP UNDIP Semarang, Tidak Dipublikasikan.
Sukirno, Sadono, 2006, Ekonomi Pembangunan: Proses, Masalah, dan Dasar Kebijakan, Kencana, Jakarta.

Suparmoko M, 2001, Ekonomi Publik Untuk Keuangan dan Pembangunan Daerah; Edisi Pertama, Andi, Yogyakarta.

Suryana, 2000, Ekonomi Pembangunan Problematika dan Pendekatan, Edisi Pertama, Penerbit Salemba Empat: Jakarta. Aplikasi Edisi Revisi, Bumi Aksara, 2007. Jakarta.

Ekonomi di Indonesia, Jakarta: Penerbit Salemba Empat (PT. Salemba Emban Patria). Pembangunan Ekonomi di Dunia Ketiga, Penerbit Erlangga, Jakarta.

Tambunan, 2003, Perekonomian Indonesia, Ghalia Indonesia, Jakarta.

Ying, L.G. 2000. China's Changing Regional Disparities during the Reform Period. Journal Economic Geography, XXIV (7). http://id.wikipedia.org/wiki/Kabupat en Jember, 2013. 